九州大学学術情報リポジトリ

Kyushu University Institutional Repository

\title{
The Situation and Comparative Advantage of Soybean Production in the Mekong River Delta of Viet Nam
}

Khai, Huynh Viet

Laboratory of Environmental Life Economics, Division of International Agricultural Resource Economics and Business Administration, Department of Agricultural and Resource Economics, Graduate of Bioresource and Bioenvironmental Science, Kyushu University

Yabe, Mitsuyasu

Department of agricultural and Resource Economics, Graduate School of Bioresource and Bioenvionmental Sciences, Kyushu University

Yokogawa, Hiroshi

Faculty of Economics, Kyushu Kyouritsu University

Sato, Goshi

Department of agricultural and Resource Economics, Graduate School of Bioresource and Bioenvionmental Sciences, Kyushu University

https://doi.org/10.5109/12880

出版情報：九州大学大学院農学研究院紀要. 53 (2)，pp.607-614，2008-10-28. Faculty of Agriculture, Kyushu University

バージョン :

権利関係 : 


\title{
The Situation and Comparative Advantage of Soybean Production in the Mekong River Delta of Viet Nam
}

\author{
Huynh Viet KHAI ${ }^{1}$, Mitsuyasu YABE*, Hiroshi YOKOGAWA ${ }^{2}$ \\ and Goshi SATO
}

\author{
Laboratory of Environmental Life Economics, Division of International Agricultural Resource Economics \\ and Business Administration, Department of Agricultural and Resource Economics, \\ Faculty of Agricultural, Kyushu University, Fukuoka 812-8581, Japan \\ (Received June 27, 2008 and accepted July 16, 2008)
}

\begin{abstract}
The study briefly described the current situation of soybean production in the Mekong River Delta (MRD) by using the policy analysis matrix method (PAM). It revealed that farmers have obtained about 521,000 VND as profit and soybean has a comparative advantage. Especially, we discovered that agricultural policies given by government almost have no positive impacts on farmers. They even reduce the effect of soybean production. By analyzing the sensitivity of a PAM, the study also shown if any of the following forecasts becomes true, soybean production still has a comparative advantage: the decrease of soybean tariff from $15 \%$ to $5 \%$, the increase of fertilizer prices of $10 \%$, an increase in exchange rate VND/USD of $10 \%$.
\end{abstract}

\section{INTRODUCTION}

With about $68 \%$ farmers of total population, Viet Nam is a long traditional agricultural country whose farmers have good experience and skill. Annually, Viet Nam has been exporting a lot of agricultural products and getting a large amount of foreign currency supporting governmental budget. In recent times, due to increasing gradually the quantity of export, Vietnamese become the world's leading exporter of rice after Thailand, of cashew after Indo and rivals Brazil for first place in coffee exports. Moreover, Viet Nam also stands the topleading position of other agricultural product exporter such as rubber, black pepper and so on.

Although the contribution of farmers is very important for economy, they still get very lower income than the rest of population and this creates the gap between rural and urban areas. To solve the problems, Government has applied variety of agricultural policies to increase the farmers' income such as supporting and introducing the new technology, forming different policies to subsidy the output and input of agriculture and so on. However, up to now there are a few researches on how the agricultural policies have an impact on farmers? Whether farmers receive any benefits from policies given by the Government or not? Answering these questions is of critical importance for policy analysis. In this paper, by using the method of policy analysis matrix (PAM) to analyze the situation of the soybean production in the MRD, the study reveals clearly the answer of the above questions. Moreover, the analysis of a PAM could show if the MRD have potential development of soybean product, in other words, whether soybean culti-

\footnotetext{
1 Laboratory of Environmental Life Economics, Division of International Agricultural Resource Economics and Business Administration, Department of Agricultural and Resource Economics, Graduate of Bioresource and Bioenvironmental Science, Kyushu University

2 Faculty of Economics, Kyushu Kyouritsu University

* Corresponding author (E-mail: yabe@agr.kyushu-u.ac.jp)
}

vation has a comparative advantage in the MRD in separate, in Viet Nam in general or not. The result of study can partly provide policy makers and others who are interested in agricultural economics more information about the situation of agriculture in Viet Nam.

The first section of the study discusses the calculation of cost and benefit analysis (CBA) and the theoretical framework and some useful policy parameters of a PAM. The second section reviews the current situation of soybean production in the MRD. The third section presents results, some sensitivity analyses of a PAM and policy simulations to help determine the likely changes on PAM's parameters and the finally some conclusions.

\section{SOURCE OF DATA}

Both primary and secondary data are used in the study.

\section{Primary data}

In the Mekong River Delta, soybean cultivation can be mainly grown in 4 provinces: such as An Giang, Dong Thap, Can Tho, Soc Trang. Basing on the location of provinces, we can divide 4 provinces into 2 different sectors. An Giang and Dong Thap represent the upper Mekong River Delta and Can Tho and Soc Trang represent the lower Mekong River Delta.

Because of the limitation of survey cost and time, depending on the convenience in organizing the field trip, An Giang that represents the upper Mekong Delta region and Can Tho that represents the lower Mekong Delta region were chosen to collect primary data. In An Giang and Can Tho, we took surveys randomly. Total samples are 113 farms. In which, 56 farmers in Can Tho and 55 farmers in An Giang were interviewed directly.

\section{Secondary data}

This data were mainly collected from the agricultural offices and departments, the authorities of different levels, agricultural extension service staffs, the heads of 
the agricultural clubs and effective farmers, especially through internet, and so on.

\section{METHODOLOGY}

In order to meet the different objectives, this study applies different frameworks. For performing the situation of soybean production, the cost and benefit analysis (CBA) is applied to evaluate the contribution of soybean production at the household level. The method of Policy Analysis Matrix (PAM) is applied to measure the comparative advantage of soybean production.

\section{Cost and benefit analysis (CBA)}

The method uses the primary data collected directly from farmers to calculate the costs, incomes and profits of soybean production. Then, some financial ratios as profit per income ratio, profit per total costs ratio, income per cost ratio and profit per family labors ratio are estimated and evaluated.

\section{The policy analysis matrix (PAM)}

The PAM is a tool which generates policy indicators for which values can be estimated, notable among which are the nominal protection coefficient, effective protection coefficient, private cost ratio and domestic resource cost ratio. In addition to Monke and Pearson's book, other textbook accounts of the application of PAM include Harrigan, Loader and Thirtle (1992, ch.7), and Scarborough and Kydd (1992, ch.5).

Regarding practical issues addressed by the PAM, Monke and Pearson (1989, p.17) state that the PAM is relevant to three areas of economic analysis:

- The impact of policies on the competitiveness of commodity systems;

- The impact of investment policy on economic efficiency and comparative advantage;

- The effects of agricultural research policy on steering the processes of technological change in desirable directions.

The PAM is constructed through double entry bookkeeping, with the purpose of ensuring complete and consistent coverage of all policy influences on the returns to, and costs of, agricultural production or marketing. Indicators of the economic consequences of policies can be derived from the parameters in the matrix. The main empirical task is to construct accounting matrices of revenues, costs and profits. A PAM is constructed for each commodity system to be analyzed. Thus, the impact of commodity and macroeconomic policies is gauged by comparing results in the presence and the absence of policy.

The PAM consists of revenues, costs and profits, at private and social (often called 'shadow') prices. The top row of the matrix is a budget showing costs of production and marketing at market prices, the only unusual aspect being the division of cost elements into two categories: tradable and non-tradable inputs (usually defined as domestic resources - the immovable domestic factors of production).
The second row in the matrix shows the same cost elements expressed at social prices, i.e. social opportunity cost. For tradable products, adjusted world prices are normally taken as social prices, applying import or export parity measures as appropriate. The social price of domestic resources is taken as their opportunity cost, in other words the return at the margin in the best available alternative.

Table 1. The Policy Analysis Matrix (PAM)

\begin{tabular}{lcccc}
\hline & Revenues & $\begin{array}{c}\text { Tradable } \\
\text { input } \\
\text { costs }\end{array}$ & $\begin{array}{c}\text { Domestic } \\
\text { factor } \\
\text { costs }\end{array}$ & Profits \\
\hline Private accounts & $\mathrm{A}$ & $\mathrm{B}$ & $\mathrm{C}$ & $\mathrm{D}$ \\
Social accounts & $\mathrm{E}$ & $\mathrm{F}$ & $\mathrm{G}$ & $\mathrm{H}$ \\
Divergences & $\mathrm{I}$ & $\mathrm{J}$ & $\mathrm{K}$ & $\mathrm{L}$
\end{tabular}

Note: Private Profits: D=A-B-C; Social Profits: $\mathrm{H}=\mathrm{E}-\mathrm{F}-\mathrm{G}$; Output Transfers: I=A-E; Input Transfers: J=B-F; Factor Transfers: K=C-G; Net Transfers: L=D-H Source: Monke and Pearson (1989).

An important general point about the PAM is that the opportunity costs of domestic resources will be a function of current policy. Thus, strictly, these opportunity costs are only relevant under a particular set of policy constraints, i.e. they are constrained second best equilibrium values. If policy was to change, so would opportunity costs. For this reason, the PAM is not wholly satisfactory in terms of economic theory, being based on a partial equilibrium rather than general equilibrium approach. It is a pragmatic, indicative approach to policy, which recognizes that practitioners of policy analysis will only rarely have the data or the time to construct a fully specified general equilibrium model capable of generating useful estimates of opportunity costs under different policy scenarios.

The third row of the PAM is simple the first row minus the second. It shows the net impact of: market failure; distorting policies; and efficient policies (those which correct market failure). The signs of the revue and cost terms in the third row indicate whether the net effects of policy and market imperfections for these categories amount to an implicit subsidy or tax. If for example, I letter were positive, the net effect of policy or market failure is that the market price paid to the system is in excess of the social opportunity cost, i.e. output prices are subsidized. The right-hand entry in the third row, $\mathrm{L}$, summaries the net effect of polices or market failures on the profitability of the system, known as 'net transfers'. If $\mathrm{D}>\mathrm{H}$, then the net effect of policy is to subsidize the system. In this case, policy reforms to bring about greater economic efficiency will reduce the gap between $\mathrm{D}$ and $\mathrm{H}$, and this will induce adjustments in the commodity system in question, which may involve changes in the proportions in which resources are used and, at least in the short term, some contraction in the scale of operation.

Regarding indicators in the PAM, the basis PAM per- 
mits twelve indicators of economic efficiency, six of which are non-ratio indicators and six are ratio-indicators. Ratio measures are more useful for comparison of commodity systems which are dissimilar in the relative proportions in which they use inputs.

Some popular indicators derived from the PAM include

The primary objective of constructing a PAM is to derive a few important policy parameters for policy analysis. Four most commonly used parameters are domestic resource cost (DRC), nominal protection coefficient output (NPCO), nominal protection coefficient input (NPCI) and effective protection coefficient (EPC).

Domestic Resource Cost Ratio (DRC)

$\mathrm{DRC}$ is the ratio of domestic factor cost valued at social prices to the value-added created by the same resources at social prices. In table $1, \mathrm{DRC}=\mathrm{G} /(\mathrm{E}-\mathrm{F})$. It is, in fact, a social cost-benefit ratio which helps determine the desirability of certain domestic production system relative to the international market in terms of economic efficiency. The social cost is the opportunity cost of domestic resources involved in the production process. The social benefit is the value-added generated by the resources measured at social prices. If the cost is greater than the benefit (DRC $>1$ ), the production of the product is not desirable from the social point of view. On the other hand, if the cost is less than the benefit $(\mathrm{DRC}<1)$, the production of that product is socially desirable. If the cost is equal to the benefit $(\mathrm{DRC}=1)$, it is just worthwhile to produce the commodity. It also implies that in regard to the commodity in question, the allocation of productive resources have reached of domestic resources would reduce the country's welfare. Nominal Protection Coefficient Output (NPCO)

$\mathrm{NCPO}$ is the ratio of domestic market price of a product to its parity price at the farm-gate. In table 1 , $\mathrm{NCPO}=\mathrm{A} / \mathrm{E}$. If $\mathrm{NPCO}>1$, it indicates that the private price of output is greater than its parity price and hence producers are positively protected for the product. If $\mathrm{NPCO}<1$, it indicates that producers are implicitly taxed on the product. If $\mathrm{NCPO}=1$, it indicates a neutral situation.

Nominal Protection Coefficient Input (NPCI)

NPCI is the ratio of the private to the social values of all the tradable inputs (or input components). In table
$1, \mathrm{NPCI}=\mathrm{B} / \mathrm{F}$. If NPCI $>1$, it indicates that producers are taxed when they buy tradable inputs. If $\mathrm{NPCI}<1$, it indicates that they are subsidized. NPCI=1 represents a neutral situation.

\section{Effective Protection Coefficient (EPC)}

NPCO and NPCI consider the distortion of government policy in the product and tradable input markets respectively in isolation. EPC measures the total effects of intervention in both markets. It is defined as the ratio of value-added measured at private prices to that at social prices, or $\mathrm{EPC}=(\mathrm{A}-\mathrm{B}) /(\mathrm{E}-\mathrm{F})$. If $\mathrm{EPC}>1$, it implies that the overall impact of the existing policy results in a net positive incentive to produce the commodity. $\mathrm{EPC}<1$ represents a net disincentive. $\mathrm{EPC}=1$ implies either no intervention or impact of various distortions in both the input and product markets results in a neutral effect on value-added.

\section{THE SITUATION OF SOYBEAN PRODUCTION IN THE MRD}

In the MRD, paddy rice is the main crop. Farmers often apply mixed farming systems such as: one-rice and one-fish crop, two-rice and one-vegetable crop, and etc to improve income and soil conditions. Consequently, farmers grew soybean in only one crop per year. The crop started in January and February after the WinterSpring rice crop and finished in March and April.

Most of soybean could be grown after a rice crop is harvested in a year and the time of soybean planning is about at the end of January or beginning February. The period between sowing and forming sapling is around 2 weeks. The growth of soybean depends on sunshine and temperature in a day. Soybean can get Nitrogen in the air for growing and help land prevent from aridity thank to its roots reaching deeply in the ground. The height of Soybean is possibly $2-3$ feet. We can get $60-80$ fruits in a tree and there are $2-4$ seeds in a fruit.

Table 2 shows the structure of soybean costs, the average cost per $1000 \mathrm{~m}^{2}$ of soybean production in the sample was about 860,000 VND. Of which, there was little difference in total costs between two regions. Farmers in An Giang cost around 937,000 VND and 800,500 VND for Can Tho farmers.

Table 2 shows that machinery, pesticide and fertiliz-

Table 2. Costs of soybean production in two provinces of the MRD

Unit: VND/1000 $\mathrm{m}^{2}$

\begin{tabular}{|c|c|c|c|c|c|c|}
\hline \multirow[b]{2}{*}{ Items } & \multicolumn{2}{|c|}{ An Giang } & \multicolumn{2}{|c|}{ Can Tho } & \multicolumn{2}{|c|}{ Overall } \\
\hline & $\begin{array}{l}\text { Amount } \\
\text { (VND) }\end{array}$ & $\begin{array}{c}\text { Proportion } \\
(\%)\end{array}$ & $\begin{array}{l}\text { Amount } \\
\text { (VND) }\end{array}$ & $\begin{array}{c}\text { Proportion } \\
(\%)\end{array}$ & $\begin{array}{l}\text { Amount } \\
\text { (VND) }\end{array}$ & $\begin{array}{c}\text { Proportion } \\
(\%)\end{array}$ \\
\hline Seed & $89,970.19$ & 9.6 & $62,820.68$ & 7.8 & $76,018.14$ & 8.8 \\
\hline Fertilizers & $184,588.96$ & 19.7 & $186,373.35$ & 23.3 & $185,525.13$ & 21.6 \\
\hline Pesticides & $232,622.42$ & 24.8 & $166,696.99$ & 20.8 & $198,784.59$ & 23.1 \\
\hline Irrigation & $24,327.32$ & 2.6 & $14,944.31$ & 1.9 & $19,588.63$ & 2.3 \\
\hline Hired labor & $179,691.60$ & 19.2 & $56,250.98$ & 7.0 & $113,236.43$ & 13.2 \\
\hline Machinery & $225,777.80$ & 24.1 & $313,380.33$ & 39.1 & $267,105.12$ & 31.0 \\
\hline Total cost & $936,978.29$ & 100.0 & $800,466.64$ & 100.0 & $860,258.04$ & 100.0 \\
\hline
\end{tabular}

Source: survey data. 


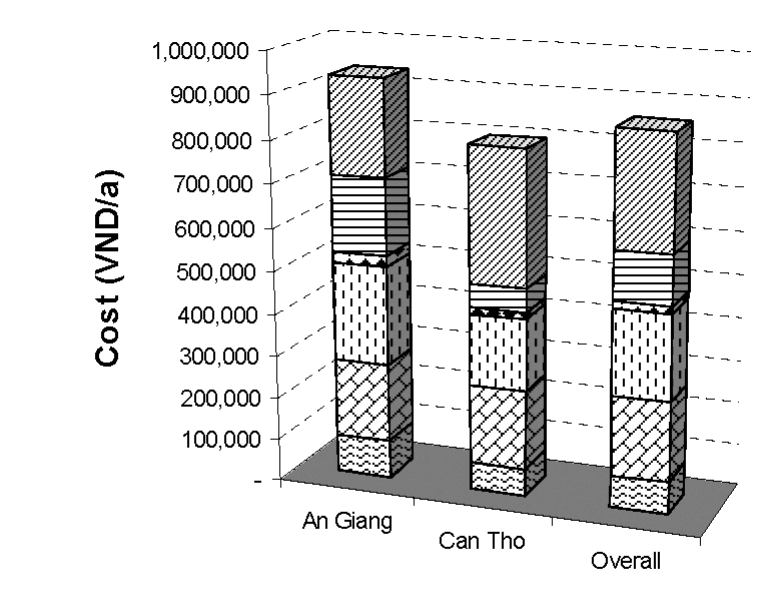

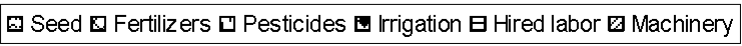

Fig. 1. Costs of soybean production, the MRD.

er costs accounted for $31 \%, 23.1 \%$ and $21.6 \%$, respectively, taking the biggest parts in the total costs. Machinery was almost constant over the crops while pesticide and fertilizer may be largely changed by crops in accordance with the changes in climatic and pest conditions. The costs of hired labor also made up a big part in soybean production, accounting for about $13.2 \%$ of total costs. Otherwise, irrigation cost constituted the smallest part. Generally, the cost structures of the two provinces seemed to be similar to each other.

Seed: Similar to other crops, soybean producers have numerous varieties to choose from. In most cases, growers plant a certain variety because their choice for such variety largely depends on field performance, resistance to insect, pests, and disease, and availability of seeds. Several local and foreign sourced soybean varieties are grown in the Mekong region, most of which are known for their local names. Some other varieties are imported or transplanted by some seed institutions to farmers through the intercropping program of the government.

Major varieties often applied were Bong Tim (57\%), Ghep 85-day (29\%) and some other local varieties. In the Mekong Delta, the amount of seed used mainly

Table 3. Soybean variety grown in Can Tho and An Giang provinces

\begin{tabular}{lc}
\hline Variety & Percentage used \\
\hline Local variety & \\
Violet flower: & $56.6 \%$ \\
Grafted seed: & $29.2 \%$ \\
Local seed: & $4.4 \%$ \\
3-nuts seed: & $0.9 \%$ \\
Vietnam 10: & $0.9 \%$ \\
White flower: & $1.8 \%$ \\
"Nung xanh": & $0.9 \%$ \\
Foreign variety & \\
FP: & $0.9 \%$ \\
Z85: & $4.4 \%$ \\
\hline
\end{tabular}

Source: survey data. depended on the experiences of the farmers. Soybean farmers tended to select varieties that have some common characteristics such as short life, high yield, pestresistance and etc. However, farmers in two survey areas had few choices of new varieties due to the poor performance of extensive service systems.

The amount of seed applied normally based on experiences or mouth to mouth delivery among soybean farmers. This amount was $11.67 \mathrm{~kg}$ per $1000 \mathrm{~m}^{2}$ for overall sample. Farmers in An Giang used seed for sowing more than those in Can Tho was $13.92 \mathrm{~kg}$ per $1000 \mathrm{~m}^{2}$ more than $9.57 \mathrm{~kg}$ per $1000 \mathrm{~m}^{2}$. Soybean seed could be sold at the price of around $6,500 \mathrm{VND} / \mathrm{kg}$ at local market and farmers averagely spent $76,000 \mathrm{VND}$ on their soybean varieties cost.

Fertilizer: Most farmers used Urea, NPK and DAP as main fertilizers in their cultivating soybean. Besides, some of them also used others such as Phosphate, Kali, Bio, DP, animal fertilizer...

The farmer applied fertilizers with quantity basing on each of stage of soybean and the farmer's financial resource. As the result of survey at An Giang and Can Tho in 2004 showed that the rate of used fertilizer was different from among the interviewed farmers.

The study showed that farmers in An Giang and Can Tho applied the same quantity of fertilizers for their soybean cultivation and they averagely had to spend above $185,000 \mathrm{VND}$ on fertilizers. They used nearly $18 \mathrm{~kg}$ Urea, $18 \mathrm{~kg}$ NPK and $13 \mathrm{~kg}$ DAP fertilizer for $1000 \mathrm{~m}^{2}$. Moreover, there was no difference between the fertilizer price in Can Tho and that in An Giang.

Pesticides: Most of the asked farmer usually used pesticide in growing soybean. Some common kinds of pesticides being applied in soybean production are listed:

Herbicide: 2,4D, Amosac, Bacosan, Cafusat, E-kil, Oneside, Whip's, etc,

Anti-disease: Antracol, Anvil, Sicaben, Komic, etc, Pesticide: Furadan, Sipet $\alpha$, Karate, Basudin, etc,. Nutritious chemicals: Bioted, HQ 101, Ba la xanh, etc,.

Farmers in the MRD invested about 200,000 VND on pesticide cost that mostly was insecticide cost. There was a little difference amount of the pesticide applied in two regions, about 150,000 VND for An Giang farms and 135,000 VND for Can Tho farms, respectively.

Irrigation: The quantity of petrol used of sampled farmers for a crop was rather small, about 3.65 litters of petrol. It was because soybean was a big seed species and so it needed a little water intake. Water was used for keeping the environment moist. Therefore, the water intake depended on the moisture of the soil. The quantity of fuel used in An Giang was much greater than that in Can Tho, 4.69 and 2.66 litters, respectively. The difference in quantity used was due to the fact that farmers in Can Tho with small farm were able to use family labor for irrigation instead of water pump, whereas, with larger farm farmers in An Giang, farmers had to use pumps. The average cost of pumping was counted for about 19,600 VND per $1000 \mathrm{~m}^{2}$. Of which, farmers in An Giang paid more than in Can Tho. However, the cost of irriga- 
tion constituted a small part in total costs.

Labor: In growing $1000 \mathrm{~m}^{2}$ of soybean, in An Giang, the labor use was 9.68 days. Of which, the number of family labor was 4.87 days. Meanwhile, in Can Tho, the amount of labor use was likely less than in An Giang with the number of 6.79 days. Of which, the amount of family labor was 4.24 days. Farmers used a great part of family labor in farming to save the cost of labor. Especially, for small farms, family labor accounted for most of labor use. They made use of spare family labor to increase income and to spend their free time.

Machinery: In soybean growing, machinery was used for preparing land, harvesting and irrigating. About 2/3 farmers used machinery to harvest, around 1/3 for land preparation and few for irrigation. The cost of machinery used was about 226,000 VND and 313,000 VND per $1000 \mathrm{~m}^{2}$ for farmers in An Giang and Can Tho, respectively.

Yield, income, profit and some financial ratio of soybean production: By taking together the information of yield and price, the income was estimated. The result of profit calculated by using income minus the total cost of soybean production could be presented in the following table 4.

As seen in table 3 , the difference in yield across two

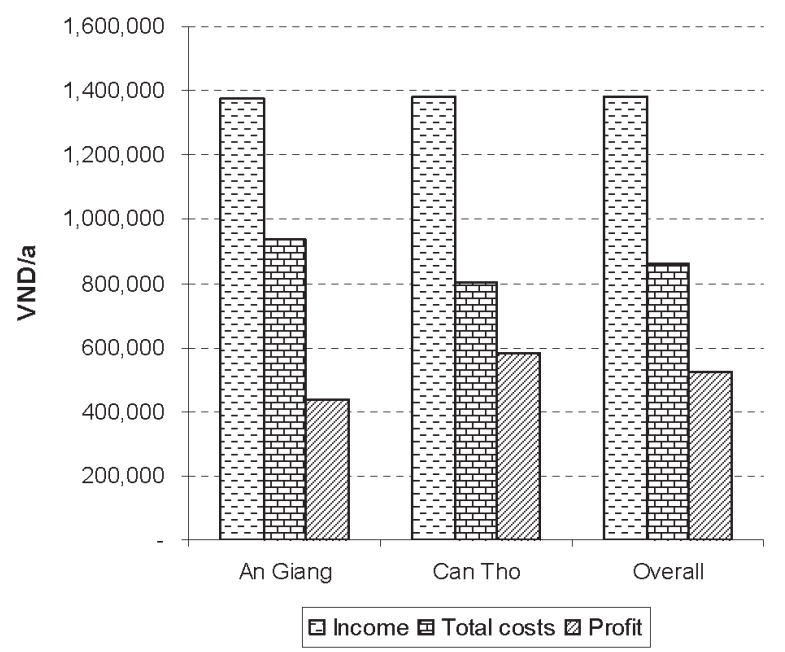

Fig. 2. Yield, income and profit of soybean production in the MRD. provinces was counted for about $18 \mathrm{~kg} / 1000 \mathrm{~m}^{2}$. An Giang farmers had the higher yield. The average yield of the sample was estimated at $267.79 \mathrm{~kg} / 1000 \mathrm{~m}^{2}$.

According to the survey data, the average price of soybean was about 5,000 VND per kilogram in An Giang and 5,300 VND per kilogram in Can Tho. There was a big variation in price across farmers. The minimum price was only $1,000 \mathrm{VND} / \mathrm{kg}$, while the maximum was $7,000 \mathrm{VND} / \mathrm{kg}$. The reasons for the big variation may come from the differences in output quality, the time of selling and the changes in market factors. Normally, the output price was fixed by the purchasers. However, sometimes, it was formed by the negotiation between buyers and sellers. At harvesting time, the buyers came to the farm to buy products at the farm-gate. Few farmers were able to sell their products at market prices because of the lack of market information. Farmers were forced to sell at low prices almost as soon as they harvested since they lacked capacity to store products for a long time in terms of poor storage technologies and lack of financial capacity for daily living.

The average income was around 1,381,600 VND/1000 $\mathrm{m}^{2}$ in Can Tho and 1,380,000 VND/1000 $\mathrm{m}^{2}$ in An Giang. There was little difference in income between two areas. While farmers in An Giang obtained the high yields but low output prices, farmers in Can Tho were in contrary situation.

Almost all farmers had profit from soybean production and received about $521,000 \mathrm{VND} / 1000 \mathrm{~m}^{2}$ for their profit excluding the family labors. The profit got by farmers in An Giang was higher than that in Can Tho. There was a big difference in profit among surveyed sample. It was mainly affected by the factors of used input, yield and output prices and also affected by other factors such as the real situation of farm, land quality and weather condition, the soybean quality and the time of selling...About $20 \%$ had negative profit and the maximum profit was obtained around 1.767 million VND.

In Vietnamese rural area, family labor was considered as the source of income. Farmers could increase more their income by family labor. The profit/family labor ratio was the earning of farmers received in their own land. This ratio in two provinces was much higher than the price of hired labor indicating that it was more profitable to do their own farming than to give hired

Table 4. Yield, income and profit of soybean production in two provinces of the MRD

\begin{tabular}{|c|c|c|c|}
\hline & Can Tho & An Giang & Overall \\
\hline Yield (kg/a) & 277.01 & 259.04 & 267.79 \\
\hline Price (VND/kg) & $4,974.55$ & $5,333.62$ & $5,158.85$ \\
\hline Income (VND/1000 m²) & $1,378,006.98$ & $1,381,598.04$ & $1,381,462.72$ \\
\hline Total costs (VND/1000 m²) & $936,978.29$ & $800,466.64$ & $860,258.04$ \\
\hline Profit (VND/1000 $\mathrm{m}^{2}$ ) & $441,028.69$ & $581,131.40$ & $521,204.68$ \\
\hline Family labor (days/1000 m²) & 4.87 & 4.89 & 4.88 \\
\hline Profit/Income ratio & 0.3 & 0.4 & 0.4 \\
\hline Profit/Total costs ratio & 0.5 & 0.7 & 0.6 \\
\hline Income/Total costs ratio & 1.5 & 1.7 & 1.6 \\
\hline Profit/family labor ratio & $90,544.25$ & $118,730.95$ & $106,738.45$ \\
\hline
\end{tabular}

Source: survey data. 
labor. With high returns on family labor, around 106,000 VND per family labor, farmers preferred working on their land to working other lands as hired labor. However, some farmers having small land had to hire out labor for others.

The ratio of income and total cost was 1.6 indicating that farmers could spend $1 \mathrm{VND}$ on soybean cost and then receive $1.6 \mathrm{VND}$ of income in which there was $0.6 \mathrm{VND}$ of profit for farmers. As you knew, farmers could really obtain profit from soybean cultivation. However, due to small areas of cultivation, the absolute amount of cash income of farmers was relatively low. On the other hand, poor farming techniques and lack of market information resulted in unstable yields and prices that may not ensure the sustainable income for farmers.

\section{THE COMPARATIVE ADVANTAGE OF SOYBEAN PRODCTION}

The basic information needed for compiling a PAM are yields, input requirements, and the market and social prices of inputs and outputs. The major sources of data used for the private account in the PAM are farm household survey data in 2004. The survey was conducted in Can Tho and An Giang province of the MRD by staff of Can Tho University. The number of households in the survey is 113 and varies across soybean activities in two provinces.

The most difficult task for constructing a PAM is the estimation of social prices and the decomposition of inputs into their tradable and non-tradable components.
We use the world price as a reference price. In the study, the social price of soybean is the respective import parity price of soybean equivalents at the farm gate as it is importing commodity. The CIF import price of soybean is collected in the website of Ministry of Agriculture and Rural Development. The CIF price is adjusted to be compared at the farm gate by adding it to the transportation from HCM port, one of the biggest ports in Viet Nam, to the whole markets. The value of transportation is assumed to be equal to 1 percent of the CIF price of soybean. The social price of soybean at the farm gate is then calculated by subtracting the distribution costs to farm.

As for tradable inputs, Viet Nam has been importing chemical fertilizer, pesticides, fuel and other major farm inputs from international markets. Thus, the tradable inputs for fertilizer, fuel are the respective import parity prices at the farm gate and the social price of soybean seed is assumed to be equal to 20 percent of the social soybean price. However, because of complication of pesticide price, the social price of pesticides was not calculated in the study. Regarding domestic factors, since these factors are not tradable internationally and thus do not have world price, their social opportunity costs are estimated through observations of rural factor markets. The domestic inputs in the study are hired labor and machinery which are assumed to be equal to the maximum prices in sample.

When the parity prices of soybean and inputs are estimated, the shadow exchange rate instead of the official exchange rate is used to convert the international

Table 5. Private and social revenues, costs and profits of soybean in the MRD

Unit: VND/1000 $\mathrm{m}^{2}$

\begin{tabular}{|c|c|c|c|c|c|c|}
\hline \multirow{2}{*}{ Quantities } & \multicolumn{3}{|c|}{ Private values } & \multicolumn{3}{|c|}{ Social values } \\
\hline & An Giang & Can Tho & Overall & An Giang & Can Tho & Overall \\
\hline \multicolumn{7}{|l|}{ Tradable factors } \\
\hline \multicolumn{7}{|l|}{ Fertilizer } \\
\hline Urea & 61,188 & 57,957 & 59,543 & 46,425 & 42,690 & 44,508 \\
\hline$N P K$ & 58,730 & 69,740 & 64,373 & 45,213 & 53,264 & 49,346 \\
\hline$D A P$ & 51,210 & 54,472 & 52,898 & 43,410 & 44,923 & 44,187 \\
\hline Other fertilizer & 13,462 & 4,205 & 8,711 & 13,462 & 4,205 & 8,711 \\
\hline \multicolumn{7}{|l|}{ Pesticide } \\
\hline Herbicide & 45,665 & 22,231 & 33,637 & 45,665 & 22,231 & 33,637 \\
\hline Fungicide & 17,754 & 6,887 & 12,177 & 17,754 & 6,887 & 12,177 \\
\hline Insecticide & 151,778 & 122,718 & 136,862 & 151,778 & 122,718 & 136,862 \\
\hline Other pesticide & 17,426 & 14,860 & 16,109 & 17,426 & 14,860 & 16,109 \\
\hline Seed & 89,970 & 62,821 & 76,018 & 95,643 & 65,773 & 80,175 \\
\hline Fuel of Irrigation & 24,327 & 14,944 & 19,589 & 34,018 & 19,285 & 26,456 \\
\hline \multicolumn{7}{|l|}{ Domestic factors } \\
\hline Hired labor & 179,692 & 56,251 & 113,236 & 351,033 & 138,596 & 241,994 \\
\hline \multicolumn{7}{|l|}{ Machinery } \\
\hline Land preparation & 26,142 & 80,851 & 51,996 & 38,124 & 104,116 & 72,012 \\
\hline Irrigation & - & 62,748 & 32,207 & - & 198,198 & 101,730 \\
\hline Harvest & 199,272 & 161,483 & 178,500 & 364,102 & 333,103 & 348,191 \\
\hline Other machinery & 364 & 8,298 & 4,402 & 364 & 8,298 & 4,402 \\
\hline \multicolumn{7}{|l|}{ Output } \\
\hline Total Revenue & $1,378,007$ & $1,381,598$ & $1,381,463$ & $1,585,993$ & $1,483,074$ & $1,533,168$ \\
\hline Total costs (excluding land) & 936,978 & 800,467 & 860,258 & $1,264,416$ & $1,179,150$ & $1,220,495$ \\
\hline Profit (excluding land) & 441,029 & 581,131 & 521,205 & 321,578 & 303,925 & 312,672 \\
\hline
\end{tabular}

Source: Own estimates; data appendix available from authors. 
Table 6. Results of the PAM analyses of soybean

\begin{tabular}{lrrrl}
\hline & \multirow{2}{*}{ Revenues } & \multicolumn{2}{c}{ Costs } & \multirow{2}{*}{ Profits } \\
\cline { 3 - 4 } & & Tradable & Factors & \\
\hline \multirow{2}{*}{ An Giang } & & & & \\
Private & $1,378,006.98$ & $531,508.89$ & $405,469.40$ & $441,028.69$ \\
Social & $1,585,993.28$ & $510,793.46$ & $753,622.20$ & $321,577.62$ \\
Divergences & $-207,986.30$ & $20,715.43$ & $-348,152.80$ & $119,451.06$ \\
\hline \multicolumn{1}{c}{ Can Tho } & & & & \\
Private & $1,381,598.04$ & $430,835.33$ & $369,631.31$ & $581,131.40$ \\
Social & $1,483,074.31$ & $396,837.71$ & $782,311.92$ & $303,924.67$ \\
Divergences & $-101,476.27$ & $33,997.61$ & $-412,680.61$ & $277,206.73$ \\
\hline$\quad$ & & & \\
$\quad$ Overall & & & & \\
Private & $1,381,462.72$ & $479,916.49$ & $380,341.55$ & $521,204.68$ \\
Social & $1,533,167.61$ & $452,166.02$ & $768,329.20$ & $312,672.40$ \\
Divergences & $-151,704.89$ & $27,750.48$ & $-387,987.65$ & $208,532.28$ \\
\hline
\end{tabular}

Source: Own estimates; data appendix available from authors.

Table 7. The results of some ratio of a PAM

\begin{tabular}{ccccc}
\hline Ratio & Formula & An Giang & Can Tho & overall \\
\hline DRC & G/(E-F) & 0.70 & 0.72 & 0.71 \\
NPCI & B/F & 1.04 & 1.09 & 1.06 \\
NPCO & A/E & 0.87 & 0.93 & 0.90 \\
EPC & $(\mathrm{A}-\mathrm{B}) /(\mathrm{E}-\mathrm{F})$ & 0.79 & 0.88 & 0.83 \\
\hline
\end{tabular}

Source: Own estimates; data appendix available from authors.

prices in US dollars into VND. In the study, shadow exchange is assumed to be $16,000 \mathrm{VND} / \mathrm{USD}$ for calculating the social prices of soybean and its inputs.

After the calculation of private and social prices for tradable, non-tradable inputs and soybean, table 5 shows a farm budget. The table is divided into two blocks. The first block records private prices, calculates the costs of inputs, and separates these costs into their tradable and non-tradable components. The second block is similar to the first block but all the values are calculated in social prices.

The principal determinant of transfers to the farm production activity is the difference between world and domestic prices. The study shows that farmers received a private soybean price of 5,159 VND per kilogram. The CIF price of soybean was 5,725 VND per kilogram equivalent to a farm-gate social price (after converting to social costs and subtracting the social value of transport costs). For $1000 \mathrm{~m}^{2}$ of soybean, private profit was 521,205 VND, while social profit was only 312,672 VND.

The summary information from table 5 is extracted to form a PAM of soybean production in the MRD as shown in table 6 and the summary results are reported in table 7 .

Based on information provided in the table 7 , the DRC of soybean-farming system is 0.71 less than 1 . This result indicates that soybean system has a comparative advantage. Growing Soybean in Can Tho is as efficient as that in An Giang because DRC of two provinces are nearly the same. In other words, soybean production in An Giang has the same comparative advantage to that in Can Tho.

The NPCOs of soybean in Can Tho and An Giang are slightly different. The NPCOs of Can Tho and An Giang were 0.93 and 0.87 , respectively. Both values of NPCO are less than 1 . This result indicates that soybean farmers received slightly lower prices than they would have received facing world prices or that systems are not receiving any protection of policy. Moreover, the value of NPCI is 1.06 that exceeded 1. This result indicates that soybean farmers are taxed when they buy tradable inputs.

Regarding the total effects of government intervention in the product and tradable input markets, we have the value of $\mathrm{EPC}=0.83$ less than 1 . It indicates that there is no subsidy of soybean production in the product and tradable input markets from government policies. The costs or profits of soybean producers are 17 percent less than they would have been in the absence of policy on output and tradable inputs.

\section{Sensitivity analysis of soybean production}

The aim of sensitivity analysis in this section is to examine whether soybean production will have compar-

Table 8. Sensitivity analysis of a PAM

\begin{tabular}{lllll}
\hline & DRC & NPCI & NPCO & EPC \\
\hline Basic scenario & 0.71 & 1.06 & 0.9 & 0.83 \\
The tariff of soybean decrease from 15\% to 5\% & 0.83 & 1.08 & 1.01 & 0.97 \\
The price of fertilizers increase 10\% & 0.72 & 1.07 & 0.9 & 0.83 \\
The exchange rate increase 10\% & 0.72 & 1.02 & 0.9 & 0.85 \\
\hline
\end{tabular}

Source: Own estimates; data appendix available from authors. 
ative advantage or not when the key factors vary and change in the future. The expected results will help answer the question "How sensitively are ratios of a PAM subject to the changes of the key factors?" In the study, relying on the situation of market fluctuation of Viet Nam, three possible scenarios of market fluctuation are assumed as the reduction of soybean tariff from $15 \%$ to $5 \%$, the addition of fertilizer prices of $10 \%$ and an increase in exchange rate of VND/USD of 10\%.

The decrease of soybean tariff: In November 2006, Viet Nam officially took part in WTO. According to WTO rule, the decrease of the tariff of import soybean products is from $15 \%$ to $5 \%$. Table 8 shows that although the soybean tariff reduces into 5\%, soybean production also has a comparative advantage since DRC is equal to 0.83 less than 1 . Moreover, $\mathrm{NPCO}=1.01$ nearly equal to 1. It indicates a neutral situation and means that there is closely no intervention of the Government in the soybean product market.

The increase of fertilizer prices: According to the annual statistics, fertilizer prices have increasing steadily and it is likely that upward trend will continue in the future. Thus, we assumed that the price of fertilizers goes up 10\% and then we investigate how the change of the PAM ratios is. The result shows that soybean farmers in the MRD have also comparative ability when the fertilizer prices ascend $10 \%$.

An increase in exchange rate of VND/\$: Recently, since VND gradually tends to loss value comparing to USD, the study assumed the increasing value of USD were 10\% comparing to VND and considered what happen to the PAM ratios. The consequence performs that there are no big changes of soybean production in the MRD after the increase of exchange rate of $10 \%$. Like the current situation, soybean cultivation receives competitiveness.

\section{CONCLUSION}

Calculating costs, income and profit of soybean, we described and estimated briefly the current situation of soybean production in the MRD. It revealed that with the average soybean yield of $268 \mathrm{~kg} / 1000 \mathrm{~m}^{2}$, farmers obtained income of 1.38 million VND. After subtracting the costs of fertilizers, pesticides, hired labors, machinery service and so on, farm received 521,000 VND for profit. Moreover, the financial ratios of soybean showed if farmer invested $1 \mathrm{VND}$ into soybean production, they could earn 1.6 VND for income and a profit of 0.6 VND. In addition, the ratio of profit/family indicated it was more profitable for MRD farmers to do their own farming than to give hired labor. In other words, they could obtained the much higher amount of opportunity cost of around 107,000 VND/day from soybean cultivation than the wage of hired labor in countryside of Viet Nam (the average wage of hired labor in sample is about 35,000 VND/day).

By applying a policy analysis matrix (PAM) to soybean production, The study shows that soybean produc- tion has comparative advantage since DRC less than 1. Some experts suggested that farmers could obtain better results if they grow alternation of rice and soybean in a year because Soybean not only increases farmer income, but also improves the quality of soil.

In the study, we especially find out that the Agricultural policies of Government almost have no positive impacts on the soybean farmers. They even reduce the effect of soybean production. Some popular governmental policies that directly support soybean farmers are agricultural extension, low-interest loan and so on. But in fact, a few farmers took part in short trainings given by agricultural extension and the large amount of them regularly borrows money through informal credit with high interest instead of receiving formal credit from banks with low interest.

Although the method of PAM cannot capture the potential changes in prices and productivity, the results of the basic scenario in table 7 are subject to changes in the market conditions. Some sensitivity analyses are estimated to catch some potential changes. The simulation results show that if any of the following forecasts becomes true, soybean production still has a comparative advantage: the decrease of soybean tariff from 15\% to $5 \%$, the increase of fertilizer prices of $10 \%$, an increase in exchange rate VND/USD of $10 \%$.

\section{REFERENCES}

Adesina, Akinwumi A. and Ousmane N. Coulibaly 1998 Policy and Competitiveness of agroforestry-based technologies for maize production in Cameroon: An application of policy analysis matrix. Agricultural Economics, 19, pp. 1-13

Fang, Cheng and John C. Beghin 2000 Food seft-suffciency, comparative advantage, and agricultural trade: A policy analysis matrix for Chinese agriculture, Center for Agricultural and Rural Development Publications 99-wp223, Center for Agricultural and Rural Development (CARD) at Iowa State University

Gotsch, Carl H., Scott R. Peason and Sjaiful Bhari 2003 Computer tutorial for policy analysis matrix in Indonesia agriculture, Stanford University

Kydd, Jonathan, Richard Pearce and Michael Stockbridge 1996 The economic analysis of commodity systems: Extending the policy analysis matrix to account for environmental effects and transactions costs. Agricultural Systems, 55(2): 323-345

Mohanty, Samarendu, Cheng Fang and Jagadanand Chaudhary 2003 Assessing the competitiveness of Indian cotton production: A policy analysis matrix approach. Journal of Cotton Science, 7: 65-74

Monke, Eric A. and Scott R. Pearson 1989 The policy analysis matrix for agricultural development, Stanford University

Nelson, Gerald C. and Martin Panggabean 1991 The costs of Indonesian sugar policy: A policy analysis matrix approach. American Journal of Agricultural Economics, 73(3): 703-712

Pearson, Scott R., Carl Garl Gotsch and Sjaiful Bahri 2003 Applications of the policy analysis matrix in Indonesian agriculture, Stanford University

Yao, Shujie 1997 Rice production in Thailand seen through a policy analysis matrix. Food Policy, 22(6): 547-560

Staal, Steven J. and Barry I.Shapiro 1994 The effects of recent price liberalization on Kenyan peri-urban dairy. Food Policy, 19(6): $533-549$ 